\title{
IMPROVED RECOVERY DEMONSTRATION FOR WILLISTON BASIN CARBONATES
}

\section{QUARTERLY TECHNICAL PROGRESS REPORT}

Cooperative Agreement DE-FC22-94BC14984

Luff Exploration Company

Denver, Colorado

Award Date: June 10, 1994

Completion Date: December 31, 1997

Government Award: \$1,778,014

\author{
Project Manager: $\quad$ Larry A. Carrell \\ Luff Exploration Company \\ DOE Project Officer: $\quad$ Chandra Nautiyal \\ Bartlesville Project Office
}

Reporting Period: October 1 - December 31, 1995

U.S. DOE Patent Clearance is not required prior to the publication of this document

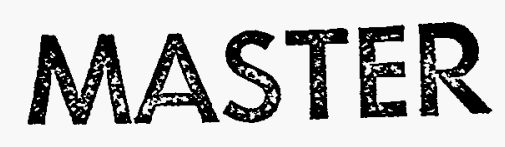

DISTRIBUTION OF THIS DOCUHEETT IS UNLMATED 


\section{IMPROVED RECOVERY DEMONSTRATION FOR WILLISTON BASIN CARBONATES}

Contract No. DE-FC22-94BC14984

Luff Exploration Company

Denver, Colorado

Contract Date: June 10, 1994

Anticipated Completion: December 31, 1997

Government Award: $\$ 1,778,014$

Principal Investigators:

Mark A. Sippel

Larry A. Carrell

Project Manager:

Chandra Nautiyal

Bartlesville Project Office

Reporting Period: Oct. 1 - Dec. 31, 1995

\section{Objectives}

The purpose of this project is to demonstrate targeted infill and extension drilling opportunities, better determinations of oil-in-place, methods for improved completion efficiency and the suitability of waterflooding in certain shallow-shelf carbonate reservoirs in the Williston Basin, Montana, North Dakota and South Dakota.

Improved reservoir characterization utilizing 3dimensional and multi-component seismic area is being investigated for identification of structural and stratigraphic reservoir compartments. These seismic characterization tools are integrated with geological and engineering studies. Improved completion efficiency is being tested with extended-reach jetting lance and other ultra-short radius lateral technologies. Improved completion efficiency, additional wells at closer spacing and better estimates of oil-in-place will result in additional oil production by primary and enhanced recovery processes.

\section{Summary of Technical Progress}

One task for the project is to test and evaluate ultrashort radius (USR) lateral completions and extendedreach jetting lance completions from existing wellbores for improved producivity and waterinjectivity. The Stearns A-19, North Buffalo field, (sec. 19, T. 21 N., R. 3 E., Harding Co., SD) was selected as a test well for this technology. The well was used for a 21-day water-injectivity test in April, 1995 to establish base-line data prior to recompletion. The well was entered in December, 1995 to prepare for a USR completion, but partial collapse of the casing prevented milling a window and running tools for drilling a lateral. Luff Exploration Company elected to bear 100 percent of these costs because lateral completion technology cannot be tested at this well.

It was elected to focus on the Richland Co. MT Ratcliffe study area for USR lateral recompletion technology at this time. Study of the Ratcliffe area has identified three areas with five wells for testing USR lateral completions and one possible waterinjection pilot. These areas were identified because of potential reserves and low recovery. Plans are to test USR lateral completions in two Ratcliffe wells. If producibility is improved as a result of USR lateral completions, plans will be developed for a waterinjection pilot in the Ratcliffe. The first completion attempt will be the Trudell M-17, North Sioux Pass field (sec. 17, T. 26 N., R. 58 E., Richland Co., MT). Work is scheduled for January, 1996. The Trudell M-17 well was evaluated by fluid-level buildup in December, 1994. This information should allow accurate engineering calculations of changes for productivity and reserves after the USR lateral completion.

A pair of Ratcliffe completions in sec. 16, T. 26 N., R. 58 E., Richland Co., MT, were found to offer the greatest potential for additional recovery by improved completion efficiency and water-injection. Nearly $5,000,000 \mathrm{bbl}\left(795,000 \mathrm{~m}^{3}\right)$ was estimated for OOIP from material-balance calculations aided by computer simulation and production type-curve analysis. Recovery from these wells is approximately $150,000 \mathrm{bbl}\left(23,800 \mathrm{~m}^{3}\right)$ with remaining economic reserves of only $40,000 \mathrm{bbl}\left(6400 \mathrm{~m}^{3}\right)$. This recovery represents only 4 percent of the potential OOIP. Oil 


\section{DISCLAIMER}

This report was prepared as an account of work sponsored by an agency of the United States Government. Neither the United States Government nor any agency thereof, nor any of their employees, makes any warranty, express or implied, or assumes any legal liability or responsibility for the accuracy, completeness, or usefulness of any information, apparatus, product, or process disclosed. or represents that its use would not infringe privately owned rights. Reference herein to any specific commercial product, process, or service by trade name, trademark. manufacturer, or otherwise does not necessarily constitute or imply its endorsement, recommendation, or favoring by the United States Government or any agency thereof. The views and opinions of authors expressed herein do not necessarily state or reflect those of the United States Government or any agency thereof. 